\title{
FLEXIBLE ADJUSTMENT OF HOTEL FACILITIES TO MARKET DEMAND
}

\section{R. MILWICZ1, P. NOWOTARSKI ${ }^{2}$}

\begin{abstract}
Accommodation tourist industry is characterized by high variability. For this category of services not only the location is crucial- that does not change, but also the standard, prices and seasonality of services. In the recent years, leisure centers performing functions only during the summer time have seen the possibility to extend their activities beyond the summer months. The reasons for this are the local investments requiring qualified staff which comes from different parts of the country, Europe and the world while creating demand for accommodations. To meet the possible demand needs and to adapt to cold season, performing thermo-modernization works is necessary. In order to find the best solution and answer those needs, analysis of the profitability of the investments in a chosen holiday resort was carried out. The article presents the results of the analysis based on the payback period, LCC analysis and assessment of the investments risk.
\end{abstract}

Keywords: LCC, life cycle cost, flexibility in construction, breakeven point

\section{BACKGROUND}

Currently, there is a growing interest in the Polish market among tourists in renting small wooden houses. Data from the Central Statistical Office says there was a 14.8\% increase in 2014 compared to 2013 of renting this type of places [2]. As a result of this fact, many owners of small holiday resorts are wondering about raising the standard of their premises and allowing guests to stay on their land also during the winter months, which in most cases requires installation of heating systems and carrying out of thermal modernization of the buildings.

\footnotetext{
${ }^{1}$ Msc. Eng., Poznan University of Technology, Division of Construction Technology and Management Institute of Structural Engineering, Piotrowo 5, 61-138 Poznan, Poland, email: roman.milwicz@put.poznan.pl

${ }^{2}$ Msc. Eng., Poznan University of Technology, Division of Construction Technology and Management Institute of Structural Engineering, Piotrowo 5, 61-138 Poznan, Poland, email: piotr.nowotarski@put.poznan.pl
} 
The authors of this paper analyze the feasibility of such upgrades based on the example of a small wooden houses complex located in Wielkopolska (PL), using flexible tools for planning and management with LCC methodology, based on historical data obtained from the owner of the object on the use of objects and projected interest in both short and long time rental in subsequent years.

\section{LCC AND FLEXIBILITY}

LCC is a powerful tool that is used for analysis of life cycle cost of the item in production, and is especially good tool to use by the construction industry where designed build objects are after a period of life they are partially recycled and reused in other location. In order to compare a number of possible options from the LCC point of view, there is a need to act in accordance with the adopted algorithm. The following steps are the basis for making investment decisions [3].

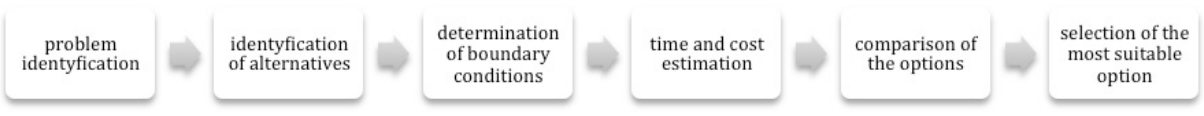

Fig. 1. Key steps in LCC analisys.

Special attention deserves the position regarding the time and cost estimation. This term in the investment time frame setting plays a key role in the estimation of the cost of the investment and its profitability. For many years investors in Poland paid attention only to the investment costs neglecting other costs associated with maintenance and energy costs. This situation is changing and with each year looks better and better.

The chart below shows a possible participation in the life cycle cost (LCC) of the object. The share of costs may take on various proportions depending on the type of the investment. Setting LCC helps to find the most optimal solution for the investor. Often, increasing the LCC is done by reduction of initial costs. A more optimized design or materials of better quality results in the future reduction in expenditure on repairs and energy demands. 


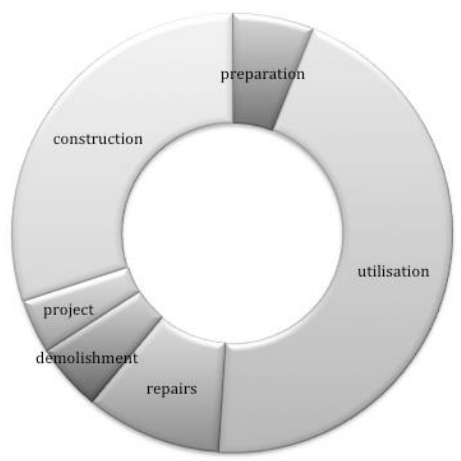

Fig. 2. Cost during life cycle of a building.[1]

The role of the designer of the building is to create a model which is adapted to the existing market trends in the best possible way [3]. Such actions are referred to in the professional literature as flexible design. This kind of design allows adjusting to the new conditions in the future, both positive and unfavorable [4]. Flexibility works in two ways: it reduces the risk during construction and increases the chances of possible benefits in the future. There are three main categories of flexibility $[5,8]$ :

- changing the size, capacity, performance,

- changing the function,

- preventing accidents.

Thanks to the flexibility idea it is also possible to lower the costs by spreading them over time: shorten the recovery time and reduce the risk of the investment. The four steps method can be helpful with the implementation of flexible solutions [7].

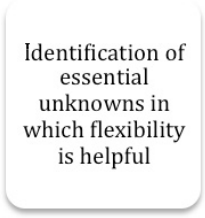

$$
\begin{aligned}
& \text { Finding } \\
& \text { elements of the } \\
& \text { system that } \\
& \text { could enable the } \\
& \text { implementation } \\
& \text { of flexibility }
\end{aligned}
$$

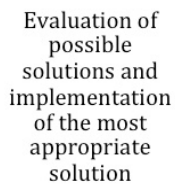
possible solutions and implementation of the most appropriate solution

The implementation plan for flexibility and results observation

Fig. 3. Four steps of flexible design.

\section{DETERMINATION OF BREAK EVEN POINT}


When making investment decisions, the important aspect is to determine the breakeven point (BEP). Figure below shows the number of sold services or products when the economic balance is zero and it's relation to: fixed costs, variable costs and sales[6]. The idea of BEP can be presented in two mathematical ways and one graphical(Fig 4.) [9]:

a) mathematical as a quantification:

$$
B E P=\frac{S}{p-k_{z}}
$$

Where: $S$-fixed costs, $p$ - selling prize of a product/service and $k_{z}$ are variable costs.

b) mathematical as a percentage of utilization of the production capacity:

$$
B E P^{\prime \prime}=\frac{S}{P_{m}\left(p-k_{z}\right)} \cdot 100 \%
$$

Where: $\mathrm{P}_{\mathrm{m}}$ is maximum production capacity.

Safety factor is also important in the assessment of the investment project. This is the key when dealing with large fluctuations of prices of sold goods or offered services. $W_{b}=0.6$ guarantees no loss when demand falls by $60 \%$ - at the same level of profit is equal zero. It is expressed by the formula (3.3):

$$
w_{b}=\frac{P_{m}-B E P}{P_{m}}
$$

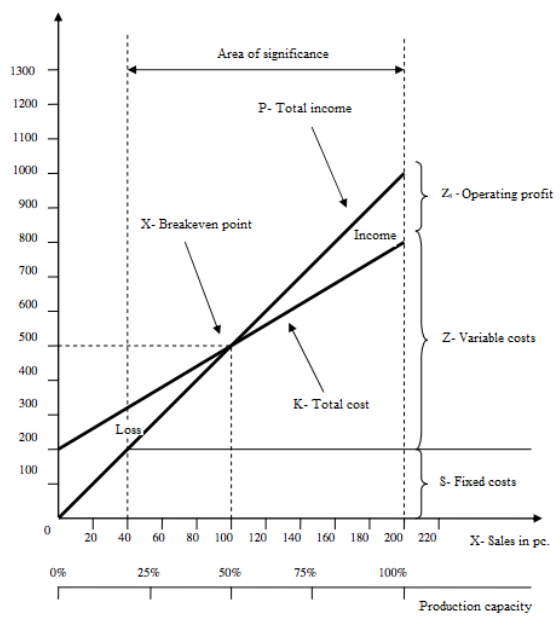

Fig. 4. Graphical idea of break even point. 


\section{Case study}

Recognizing the need for the market, investor is planning to thermo-modernize a small holiday resort in order to adapt parts of the premises to operate during the heating season. Currently there exist 3 wooden summer houses consisting of two apartments each, operating only during the summer season.(Fig. 5) Localization of a large investment in the vicinity of the holiday resort is the reason for increased demand for accommodation for employees and engineers employed in the investment also during the winter months. The planned construction period is 5 years. There is a high probability that the scope of work will be extended, hence the need for accommodation in the resort. Owners of the holiday resort commissioned the development and recalculated both options. The period of intensive use is assumed as 5 years. It was important also to determine the minimum amount of visitors, so that the resort does not generate a loss (BEP). Authors examine the possibility of making a profit that can be achieved by conducting thermos-modernization and allowing the use of apartments during the heating period. Each apartment is designed for 3 people. The cost of accommodation for long-term rental is $20 \mathrm{PLN}$ net for one person per day.
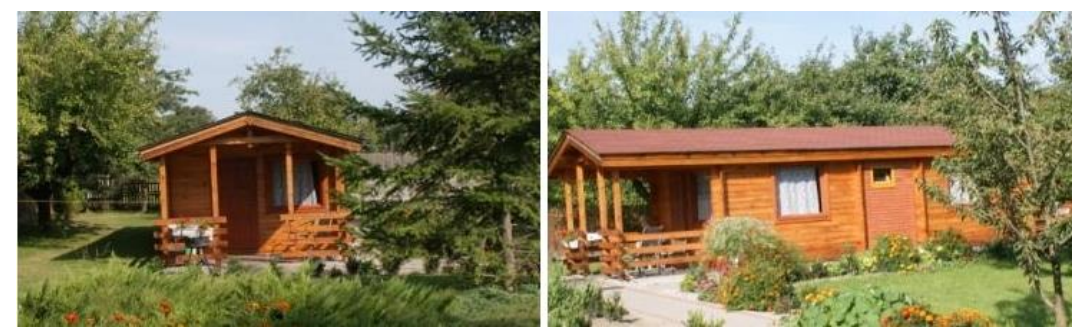

Fig. 5. Apartments for modernization.

Calculation of possible income and costs was performed to find the best thermos-modernization solution for this case.

Thermo-modernization process in general includes 2 steps [10]:

1. replacement of the building's window and wall insulations,

2. installation of (A) electrical radiant system, or (B) pellet's central heating system.

The total cost of the modernization with both heating system options were analyzed in this article. Authors were focused on showing the positive and the negative aspects for each option. Both options for heating system A and B are characterized by high flexibility, but with completely different properties. 
In option (A) electric radiators require low investment costs related to the purchase and installation. The installation time is very short and possible during having guests accomodated at the resort. This is a significant advantage because it does not generate aditional profit and reputation losses. The ability for changing of the radiator to other sources of heat is also hassle-free, plus there is always a possibility for re-using radiators in other facilities. Level of failure for this kind of equipment is very low and is of localized importance (failure of one radiator has no effect on other sources of heat). In order to reduce power consumption, each heater can be equipped with a timer. The use of such a method is possible by both low thermal capacity of the building -timber structure, which in this case turned out to be an advantage, as well as the regularity and predictability of users staying on the premises. Guests arrive at homes from 7:00pm to 6:00am. This allows to set the heating in the bedroom between 6:00pm-6.00am and in the bathroom 6:00am-9.00pm and 5.00am-6.00am. The rest of the heating time is triggered manually. This solution can reduce energy consumption while comfort of the guests remains unchanged.

In Option (B) central heating system with pellet boiler is a solution that requires more time during the installation and is connected with higher investment costs. The main difficulty is the construction of the boiler room and the connection between it and the apartments. However, this option may involve a number of benefits. First of all, this solution will reduce energy costs for heating during the winter season. Secondly, with the installation of central heating system, the replacement of the electric boilers for heating water will be conducted. This will reduce the cost of heating water throughout the whole year- savings on water heating can reach the level of $70 \%$ compared to the existing electric heating. The total installation cost is higher, but this solution allows for the use of renewable energy sources, e.g. solar collectors in the future.

\subsection{COMPARATIVE ANALISIS}

On the basis of the data received from the investor, who's been observing the historical demand for over 20 years and also owns a property with similar characteristics to those which are planned to be improved, a comparative analysis was prepared.The following numbers summarize the case study analysis for this article. 
Table1. Modernization cost of each option

\begin{tabular}{|c|c|c|}
\hline Option & A & B \\
\hline Initial costs [PLN]: & 25200 & 25200 \\
insulation & 7000 & 7000 \\
windows & 2340 & 37000 \\
heating system & & \\
& 34540 & 69200 \\
Total & 160 & 60 \\
\hline Heating [PLN/month(20days)/flat] & 2,1 & 0,7 \\
\hline Hot water [PLN/person/day] & 3000 & 3000 \\
\hline Fixed costs (S) [PLN/month] & &
\end{tabular}

An important factor which was previously mentioned in the article is the breakeven point BEP for each option. The accommodation services are characterized by a great diversity of demand, and therefore an important aspect is to select the option with a lower BEP.

Table 2. Breakeven point for each option

\begin{tabular}{|l|c|c|}
\hline Option & A & B \\
\hline Max. Capacity per month[guests] & 540 & 540 \\
\hline BEP [quests per day] & 197 & 164 \\
\hline BEP” [\%] & 36 & 30 \\
\hline $\mathrm{W}_{\mathrm{b}}$ & 0,64 & 0,70 \\
\hline
\end{tabular}

BEP presented graphically (fig.6) allows for the observation of the influence of fixed and variable costs on the profitability of the investment. Lower costs are less vulnerable to price fluctuations and thus, without long-term contracts expose the investor to reduced profits or even create losses.

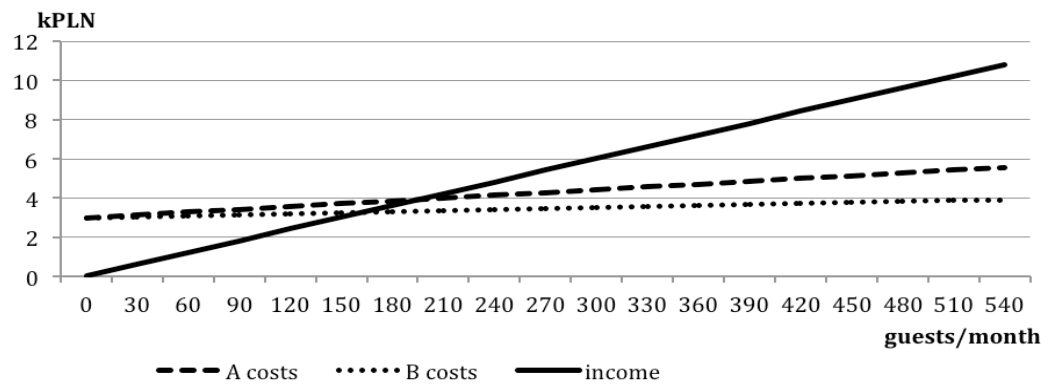

Fig. 6. Comparison of cost and income of two options.

An analysis based on life cycle cost LCC (fig.7) shows the return on investment and possible income. Option A will pay off about four months earlier than B, but what is more interesting, the 
investor's income related to the modernization of both options without modernization exceed the case essentially in the same period.

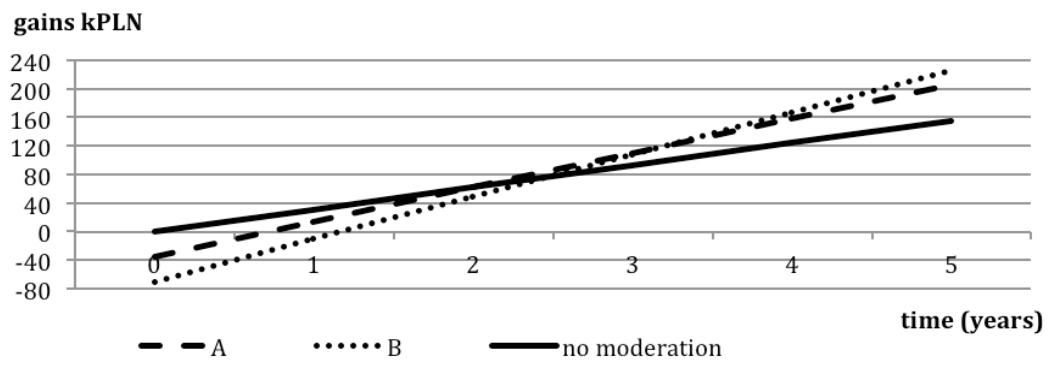

Fig. 7. Visualization of gains in time for three cases.

Investment is planned to be performed in the next five years, but after that date there is expected growth of interest in services - especially since the company is expanding its services. On the basis of data obtained from the investor, the cone of possible gains for the next 10 years was prepared (Fig. 8). The accommodation level was adopted between 40 and $60 \%$ of total capacity of the resort.

It is easy to see that option B has much better results, thanks to a low energy expenses for heating. In the case of the accommodation level below $36 \%$ for the version of $\mathrm{A}$ - which is possible based on historical data, this option will generate profits even lower than in the case of not performing thermosmodernization. The only solution in this case would be the reduction of fixed costs by changing the employment level. The investor would rather not take this type of actions.

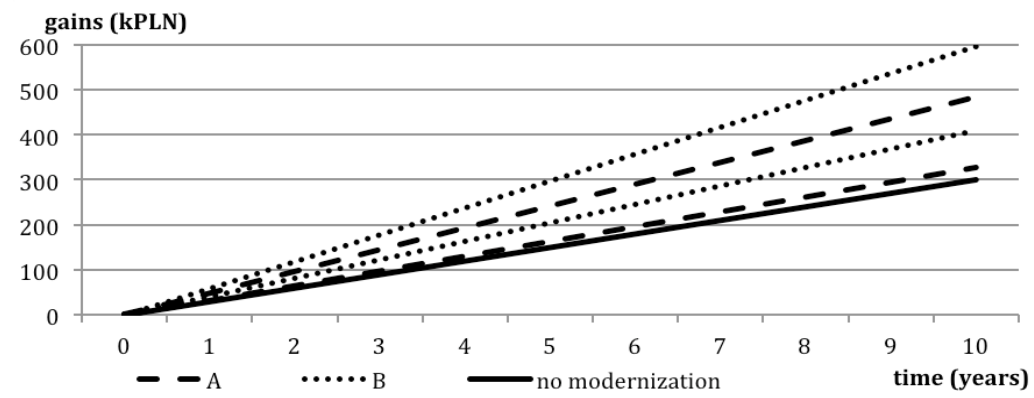

Fig. 8. Spectrum of possible gains 


\section{Conclusions}

In the course of the analysis of the case study it can be concluded that the use of several tools to develop the topic gives a wider field of view and grasps the problem from many sides. Especially the use of the LCC method can be provide necessary hints regarding which solution to follow.

The spectrum of income in Graph 3 shows the advantage of solution B, which, although more expensive, and thus risky, provides measurably greater benefits in the long term by reducing the total energy costs. This analysis of the cost of living would be even greater if the delamination energy costs have risen dramatically. Additional advantage of this option is, the future ability of adding solar collectors, which could reduce dependence on external conditions.

It can also be added that thermo-modernization in the analyzed resort can be extended to other similar premises and may result in enabling new opportunities for the owners connected with operating during the winter season plus it can maximize the total profit throughout a year for hotel services.

\section{REFERENCES}

[1] M. Arja, G. Sauce, B. Souyri, External uncertainty factors and LCC a case study Building Research \& Information (2009) 37(3),325-334

[2] Główny Urząd Statystyczny, Baza noclegowa według stanu w dniu 31 lipca 2014 r. i jej wykorzystanie w I półroczu 2014 roku.

[3] R. Kansal,G. Kadanbari, Green Buildings: An Assesment of Life Cycle Cost The IUP Journal of Infrastructure, Vol. VIII, No. 4, 2010

[4]N. Kulatilaka, The value of flexibility: The case study of dual-fuel industrial steam boiler. Financial management 22(3)(1993):271-280

[5]E. Levander, J. Schade, L. Stehn, Life Cycle Cost calculation models for buildings \& addressing uncertainties about timber housing by Whole Life Costing Life Cycle Costing for buildings: theory and suitability for addressing uncertainties about timber housing. inpro-project.eu LTU Luleå, Sweden

[6]G. Michałkiewicz, K. Prędkiewicz, Tajniki finansowego sukcesu dla mikrofirm C.H. Beck, Warszawa 2007

[7]R. Neufville, S. Scholtes, Flexibility in engineering design, Massachusetts Institute of Technology, 2011

[8]J. Pasławski, Elastyczność w zarządzaniu realizacją procesów budowlanych, Wydawnictwo Politechniki Poznańskiej, Poznań, 2009

[9] W. Rogowski, S. Kasiewicz, Zmodyfikowane metody oceny opłacalności przedsięwzięć inwestycyjnych, „Zeszyty Naukowe Kolegium Zarządzania i Finansów” nr 50, SGH, Warszawa 2004, s. 82-95.

[10]A.K. Sethi, S.P. Sethi, Flexibility in manufacturing: A survey, The International Journal of Flexible Manufacturing Systems 2, 1990 


\section{LIST OF FIGURES AND TABLES:}

Fig. 1. Key steps in LCC analysis.

Rys. 1. Kluczowe kroki w analizie LCC.

Fig. 2. Cost during life cycle of a building.

Rys. 2. Koszt podczas cyklu życia obiektu.

Fig. 3. Four steps of flexible design.

Rys. 3. Cztery kroki elastycznego projektowania.

Fig. 4. Graphical idea of breakeven point.

Rys. 4. Graficzne przedstawienie progu rentowności.

Fig. 5. Apartments for modernization.

Rys. 5. Apartamenty do modernizacji.

Fig. 6. Comparison of cost and income of two options.

Rys. 6. Porównanie kosztów i zysków dwóch opcji.

Fig. 7. Visualization of gains in time for three cases.

Rys. 7. Wizualizacjia zysków w czasie dla trzech przypadków

Fig. 8. Spectrum of possible gains.

Rys. 8 Spektrum możliwych zysków.

Tab. 1. Modernization costs of each option.

Tab. 1. Koszt modernizacji każdej z opcji.

Tab. 2. Breakeven point for each option. 


\section{ELASTYCZNE DOSTOSOWANIE OBIEKTÓW HOTELOWYCH DO WYMAGAŃ RYNKOWYCH}

Keywords: LCC, elastyczność w konstrukcji, breakeven point

\section{STRESZCZENIE:}

Branża turystyczno-noclegowa charakteryzuje się dużą zmiennością. Na zainteresowanie klientów ma wpływ nie tylko lokalizacja- która nie ulega zmianie, ale także standard, ceny oraz sezonowość usług. W ostatnich latach ośrodki pełniące funkcje jedynie letniskowe dostrzegają możliwość poszerzenia swojej działalności w miesiącach zimowych. Powodem tego stanu rzeczy są m.in. lokalne inwestycje wymagające wykwalifikowanej kadry, która to przyjeżdża z różnych rejonów kraju, Europy czy świata stwarzając popyt na miejsca noclegowe oraz gastronomiczne. Dodatkowo obserwuje się wzrost zainteresowania turystów wynajmem małych domków drewnianych w ostatnich latach na terenie Polski.

Dostosowanie się do zaistniałych potrzeb wymaga adaptacji ośrodka do tzw. chłodnego sezonu. W celu znalezienia najodpowiedniejszego rozwiązania, w jednym $\mathrm{z}$ takich ośrodków, została przeprowadzona analiza opłacalności inwestycji termo-modernizacji obiektu.

Autorzy niniejszego opracowania przeprowadzili analizę przypadku przy użyciu elastycznych narzędzi do planowania i zarządzania budową oraz za pomocą metody LCC. Użyto przy tym danych historycznych uzyskanych od właściciela, oraz przewidywanego zainteresowania zarówno krótko- jak długoterminowego wynajmu obiektu w kolejnych latach.

W celu porównania kilku możliwych opcji rozwiązań, zgodnie z metodologią LCC, należy działać według przyjętego algorytmu. Wymienione poniżej kroki stanowią podstawę podejmowania decyzji dotyczących inwestycji.

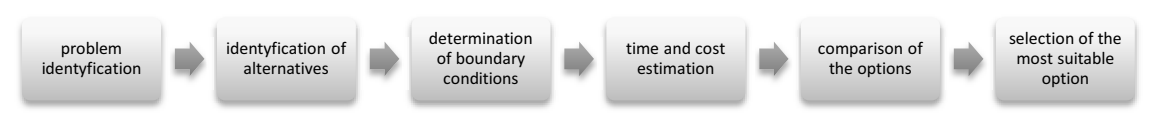

rys.1: Główne fazy analizy porównawczej LCC

Na szczególną uwagę zasługuje tutaj pozycja oszacowanie czasu i kosztów dla każdej z opcji. Określenie ram czasowych inwestycji odgrywa kluczową rolę w oszacowaniu kosztów inwestycji a co za tym idzie, także jej opłacalności. Jeszcze niedawno inwestorzy w Polsce zwracali uwagę jedynie na koszty inwestycyjne bagatelizując pozostałe koszty związane z konserwacją czy kosztami energii. Sytuacja ta z roku na rok wygląda coraz lepiej i zwiększa się świadomość inwestorów w analizowanej branży.

Udział kosztów może przybierać różne proporcje w zależności od charakteru inwestycji. Wyznaczenie LCC pomaga znaleźć rozwiązanie najbardziej optymalne dla inwestora. Często obserwowanym faktem jest obniżenie LCC dzięki zwiększeniu kosztów początkowych na np. bardziej zoptymalizowany projekt, czy też materiały o lepszej jakości, skutkują zmniejszeniem wydatków na późniejsze naprawy czy zakup/wytworzenie energii.

\section{Analiza Przypadku}

Inwestor dostrzegając potrzeby rynku planuje modernizację ośrodka w celu adaptacji części pomieszczeń na świadczenie usług w sezonie grzewczym. Zlokalizowanie dużej inwestycji w pobliżu ośrodka powoduje zwiększone 
zapotrzebowanie na miejsca noclegowe dla pracowników oraz kadry inżynierskiej zatrudnionej przy inwestycji. Planowany czas robót wynosi 5 lat. Istnieje duże prawdopodobieństwo, iż zakres prac zostanie poszerzony a co za tym idzie, konieczność zapewnienia miejsc noclegowych. Inwestor zlecił opracowanie i przekalkulowanie dwóch opcji. Jako okres intensywnej eksploatacji przyjęto 5 lat. Istotne było także ustalenie minimalnej ilości gości dla której ośrodek nie przynosi strat (BEP). W celu podjęcia przeglądu przeanalizowano możliwość zysku jaki można osiągnąć podejmując termomodernizację.

Aktualnie 3 domy letnie składające się z dwóch mieszkań przeznaczanych do termomodernizacji pełnią swoje funkcje jedynie w sezonie letnim. W toku analizy przeliczono możliwy przychód oraz koszty i znaleziono w ten sposób rozwiązanie najlepiej dopasowane do potrzeb inwestora.

W założeniach termomodernizacja ma obejmować: wymianę stolarki okiennej i ocieplenie ścian budynków oraz i instalację elektrycznych promienników ciepła(opcja A) lub instalację centralnego ogrzewania wraz z piecem na pellet (opcja B). Wady i zalety poszczególnych opcji przedstawiono poniżej.

\section{Opcja A}

Elektryczne promienniki ciepła wymagają niskich nakładów finansowych związanych z zakupem i instalacją grzejników. Również czas montażu jest bardzo krótki oraz możliwy do przeprowadzenia w trakcie pobytu gości w ośrodku. Jest to na tyle istotne, iż nie generuje strat za usługi oraz nie stwarza możliwości utraty klienta przez wyszukanie przez niego innego miejsca pobytu. Możliwość zmiany ogrzewania na inne źródła jest również niekłopotliwa, dodatkowo istnieje możliwość powtórnego użycia promienników w innych obiektach. Awaryjność promienników jest bardzo niska, a co istotne ma ona charakter lokalny (awaria jednego promiennika nie ma wpływu na pozostałe źródła ciepła). W celu obniżenia zużycia energii każdy promiennik zostałby wyposażony w czasowy programator. Wykorzystanie takiej metody jest możliwe dzięki, przede wszystkim, małej pojemności cieplnej budynku z drewna, która w tym przypadku okazuje się być zaletą, a także regularności i przewidywalności pobytu użytkowników w pomieszczeniach. Goście przybywają w domach od godziny 19.00 do 6.00. Umożliwia to ustawienie ogrzewania w sypialni na zakres 18.00-6.00 natomiast w łazience 18.00-21.00 oraz 5.00-6.00- w pozostałym czasie ogrzewanie można uruchomić manualnie. Dzięki takiemu rozwiązaniu możliwa jest znaczna redukcja poboru energii przy utrzymaniu niezmienionego komfortu cieplnego użytkowników.

\section{Opcja B}

Instalacja centralnego ogrzewania z wykorzystaniem pieca na pellet jest rozwiązaniem bardziej czasochłonnym oraz niesie za sobą większe koszty inwestycyjne. Główną trudnością jest budowa kotłowni. Jednak ta opcja może pociągać za sobą szereg korzyści. Przede wszystkim dzięki zastosowaniu tego rozwiązania inwestor zmniejszy wydatki na energię w sezonie grzewczym. Istotnym aspektem jest fakt, że w przypadku realizacji tej opcji, nastąpi także zastąpienie bojlerów elektrycznych podgrzewających CWU przez ogrzewanie centralnym piecem na pellet, co przyczyni się to do znacznej redukcji kosztów podgrzewania wody w ciągu całego roku- oszczędności wynosić mogą około $70 \%$ w porównaniu do ogrzewania elektrycznego. Podobnie jak w opcji A ogrzewanie będzie sterowane czasowo. Instalacja jest bardziej kosztownej ale umożliwia inwestorowi zastosowanie w przyszłości odnawialnych źródeł energii np. kolektorów słonecznych, które można włączyć do systemu ogrzewania.

Oba rozwiązania charakteryzują się wysoką elastycznością, posiadającą jednak związane są z zupełnie inną technologią jak i kosztami dla inwestora. W artykule przeliczono każdą opcji pod kątem LCC i opłacalności inwestycji 
na przestrzeni przyszłych 20 lat funkcjonowania ośrodka oraz zaproponowano wybór najkorzystniejszej z nich w danym przypadku.

\section{Wnioski}

Po przeprowadzaniu analizy przypadku można stwierdzić, że użycie kilku innowacyjnych narzędzi do dogłębnego badania tematu daje szersze pole widzenia i umożliwia zrozumienie problemu. Szczególnie metoda LCC zapewnia niezbędne wskazówki dla inwestora, dotyczące najlepszych rozwiązań przy wykonywaniu termo-modernizacji.

Ukazane w artykule spectrum możliwości uzyskania przychodu w momencie skorzystania z opcji B jest wyraźnie widoczne i mimo że rozwiązanie w początkowej fazie inwestycyjnej jest droższe, w dłuższej perspektywie jest korzystniejsze poprzez zmniejszenie całkowitych kosztów energii podczas użytkowania. Dodatkową zaletą tej opcji jest to, że w przyszłości może być modyfikowana o dodatkowe źródła energii i ciepła np. o kolektory słoneczne, które mogłyby dodatkowo obniżyć zależność inwestora od dostawców energii.

Warto także dodać, że proponowana metoda termo-modernizacji może być z powodzeniem używana przy realizacji podobnych inwestycji i może umożliwiać właścicielom ośrodków letniskowych wzrost przychodów związanych z obsługą ruchu pracowniczo-turystycznego również w trakcie sezonu zimowego. 